Article

\title{
Experiments with Pyrotechnic Compositions Based on a Mathematical Model-Part III: Comparative Analysis of Manufacturing Costs of Pyrotechnic Composition Producing an Acoustic Effect
}

\author{
Krzysztof Barański ${ }^{1, *(D)}$ and Jolanta Biegańska ${ }^{2}$ (D) \\ 1 Department of Mining Engineering and Work Safety, Faculty of Civil Engineering and Resource Management, \\ AGH University of Science and Technology, Aleja Adama Mickiewicza 30, 30-059 Cracow, Poland \\ 2 Department of Hydrogen Energy, Faculty of Energy and Fuels, AGH University of Science and Technology, \\ Aleja Adama Mickiewicza 30, 30-059 Cracow, Poland; biega@agh.edu.pl \\ * Correspondence: baranski@agh.edu.pl
}

check for

updates

Citation: Barański, K.; Biegańska, J.

Experiments with Pyrotechnic

Compositions Based on a

Mathematical Model-Part III:

Comparative Analysis of

Manufacturing Costs of Pyrotechnic

Composition Producing an Acoustic

Effect. Energies 2022, 15, 1331.

https://doi.org/10.3390/en15041331

Academic Editor: Léo Courty

Received: 6 December 2021

Accepted: 7 February 2022

Published: 12 February 2022

Publisher's Note: MDPI stays neutral with regard to jurisdictional claims in published maps and institutional affiliations.

Copyright: (c) 2022 by the authors. Licensee MDPI, Basel, Switzerland. This article is an open access article distributed under the terms and conditions of the Creative Commons Attribution (CC BY) license (https:// creativecommons.org/licenses/by/ $4.0 /)$.

\begin{abstract}
The article presents a comparison of the influence of price change of the components of pyrotechnic compositions producing an acoustic effect on their manufacturing costs. The analysis was based on the prices of raw materials in 1981 and 2021. The influence of price fluctuations of individual raw materials on the final cost of composites was determined. The impact of price changes on the profitability of pyrotechnic composition manufacturing was evaluated for the adopted models. The conducted economic analysis allowed for the determination of pyrotechnic compositions characterised by the lowest manufacturing costs, in terms of the unit cost, and for the assumed industrial models.
\end{abstract}

Keywords: pyrotechnic compositions; firecrackers; manufacturing costs

\section{Introduction}

In order to ensure optimum performance, pyrotechnic compositions must meet a number of technical requirements for their correct functioning and performance, related mainly to the safety of their use [1-13]. These criteria are usually defined in relevant standards and legal acts that regulate the conditions of use, manufacturing and storage [14,15]. Currently, the environmental impact of finished products is also evaluated. These requirements may change over the years, which may lead to cessation of the manufacturing of compositions that no longer meet them (e.g., as a result of tightening environmental protection standards) or necessitate modification of their components. This may also result in the need to change the methods of manufacturing using new tools or methods not directly resulting from technological change.

One of the economic criteria taken into account in the manufacture of pyrotechnic compositions is the total cost of their manufacture. For the purposes of this analysis, the term "manufacturing cost" will be used, which stands for the sum of the costs of the individual components of the pyrotechnic's composition. The analysis does not include other production costs related to, e.g., machine work, human labour, storage, transport, taxation and logistics. As the analysis was performed for data from a long period of 40 years (from 1981 and 2021), very significant social and economic changes, as well as significant technological change, took place during this period. The analysis of production costs would require the introduction of many complex variables, which would significantly increase its complexity, and the interpretation of results would be very ambiguous. In contrast, it is relatively simple to compare manufacturing costs. Cost analysis is comparative without reference to purchasing values and the real value of money for the period in question. 
Despite the passage of time, a very important economic criterion is obtaining the lowest possible manufacturing and production costs.

\section{Price Change of Groups of Components Used for the Manufacture of Pyrotechnic Compositions}

The analysis was performed for the prospective compositions selected in Part I and Part II $[16,17]$. The research on pyrotechnic compositions was based on a mathematical model of an experiment, the use of which allowed for good prediction of the performance properties of the composition, and thus, a reduction in the number of tests performed.

The compositions were tested for reliability and evaluated in terms of friction sensitivity, measurement of the sound intensity level, burning rate, flash fire temperature and the ability to perform mechanical work (Trauzl lead block test). In addition, a test concerning the change of properties of pyrotechnic compositions during storage and a determination of stability using differential thermal analysis (DTA) were also performed. The percentage content of components of individual pyrotechnic compositions along with their designations are shown in Tables 1 and 2.

Table 1. The percentage content of components of prospective pyrotechnic compositions from the M-1 group, obtained using mathematical modelling [16].

\begin{tabular}{ccccc}
\hline \multirow{2}{*}{ Designation } & \multicolumn{4}{c}{ Content of Individual Components (\%) } \\
\cline { 2 - 5 } & $\mathbf{K C l O}_{\mathbf{4}}$ & $\mathbf{F e}_{\mathbf{2}} \mathbf{O}_{\mathbf{3}}$ & $\mathbf{A l}$ & $\mathbf{S}$ \\
\hline 1A & 38 & 19 & 28 & 15 \\
$1 \mathrm{~B}$ & 42 & 13 & 30 & 15 \\
$1 \mathrm{C}$ & 38 & 15 & 32 & 15 \\
$2 \mathrm{~A}$ & 30 & 25 & 20 & 25 \\
$2 \mathrm{~B}$ & 36 & 17 & 22 & 25 \\
$2 \mathrm{C}$ & 35 & 5 & 26 & 25 \\
$3 \mathrm{~A}$ & 34 & 15 & 26 & 35 \\
$3 \mathrm{~B}$ & 35 & 10 & 27 & 35 \\
$3 \mathrm{C}$ & 28 & & 35 \\
\hline
\end{tabular}

Table 2. The percentage content of components of prospective pyrotechnic compositions from the M-1 group, obtained using mathematical modelling [16].

\begin{tabular}{ccccc}
\hline \multirow{2}{*}{ Designation } & \multicolumn{4}{c}{ Content of Individual Components (\%) } \\
\cline { 2 - 5 } & $\mathbf{K C l O}_{\mathbf{4}}$ & $\mathbf{F e}_{\mathbf{2}} \mathbf{O}_{\mathbf{3}}$ & $\mathbf{P A M}{ }^{*}$ & $\mathbf{S}$ \\
\hline $4 \mathrm{~A}$ & 36 & 18 & 26 & 20 \\
$4 \mathrm{~B}$ & 35 & 18 & 27 & 20 \\
$4 \mathrm{C}$ & 39 & 14 & 27 & 20 \\
$5 \mathrm{~A}$ & 35 & 17 & 20 & 25 \\
$5 \mathrm{~B}$ & 37 & 15 & 21 & 25 \\
$5 \mathrm{C}$ & 38 & 20 & 20 & 25 \\
$6 \mathrm{~A}$ & 30 & 13 & 20 & 30 \\
$6 \mathrm{~B}$ & 37 & 18 & 23 & 30 \\
$6 \mathrm{C}$ & 29 & & 30 \\
\hline
\end{tabular}

*An alloy with 50\% magnesium and 50\% aluminum called "magnalium" (PAM) in the form of a powder.

Price changes of individual pyrotechnic composition components in 1981 and 2021 are shown in Table 3.

Data on the prices of all raw materials in 1981 were obtained from available archival data [18]. At that time, due to the planned economy, product prices were set by the state authorities. Moreover, the number of entities able to supply the raw materials required for the manufacturing of pyrotechnic compositions was much smaller than today. In the case of data for the year 2021, in free-market conditions, it is possible to purchase components from many suppliers (domestic and foreign) both in a traditional way and via the Internet. High competition and numerous purchasing channels cause significant 
price fluctuations. Therefore, for the purposes of the analysis, the current (lowest) retail prices for $1 \mathrm{~kg}(2.20 \mathrm{lb})$ of raw materials were adopted [19-31]. Raw materials with similar chemical properties related to their purity, form and fineness were compared. Most of the ingredients of sufficient quality for the production of pyrotechnic compositions are available on popular international Auction Portals: eBay, Amazon, and also the Polish "Allegro" (the most popular Polish Auction Portal). The offer of specialised online stores selling raw materials for pyrotechnics was also taken into account. Raw materials offered by well-known chemical companies are much more expensive due to their very high purity (for chemical analyses). To simplify the analysis, the issue of duty (depending on the country of production of the pyrotechnic composition) was omitted. The time of delivery of raw materials and the ability of a given seller to supply raw materials in bulk were not taken into account. The presented price sources relate to sales in retail quantities. In the case of purchase in wholesale, the costs of raw materials would be lower and dependent on the scale of production, determined on the basis of individual arrangements between the producer and the seller. The lowest price of the seller was chosen as the basic selection criterion. All prices reported in this article have been converted to USD based on the average exchange rate of the National Bank of Poland on 15 February 2021 (USD 1 = PLN 3.6949) [32].

Table 3. Fluctuations of the unit price of pyrotechnic composition components in 1981 and 2021 [18-31].

\begin{tabular}{|c|c|c|c|c|c|}
\hline $\begin{array}{l}\text { Chemical Name } \\
\text { (Type of Compound) }\end{array}$ & $\begin{array}{l}\text { Chemical } \\
\text { Formula }\end{array}$ & $\begin{array}{c}\text { Unit Price (1981) } \\
\text { PLN/kg } \\
\text { (USD/kg) }\end{array}$ & $\begin{array}{c}\text { Unit Price (2021) } \\
\text { PLN/kg } \\
\text { (USD/kg) }\end{array}$ & $\begin{array}{c}\text { Price Difference } \\
\text { Compared to } 1981 \\
\text { PLN/kg } \\
\text { (USD/kg) }\end{array}$ & $\begin{array}{c}\text { Price Difference } \\
\text { Compared to } 1981 \text { [\%] }\end{array}$ \\
\hline Barium nitrate $(\mathrm{V})$ & $\mathrm{Ba}\left(\mathrm{NO}_{3}\right)_{2}$ & $\begin{array}{l}15.70 \\
(4.25) \\
\end{array}$ & $\begin{array}{c}68.00 \\
(18.40)\end{array}$ & $\begin{array}{l}52.30 \\
(14.15)\end{array}$ & 333.13 \\
\hline Iron(III) oxide & $\mathrm{Fe}_{2} \mathrm{O}_{3}$ & $\begin{array}{c}7.40 \\
(2.00)\end{array}$ & $\begin{array}{l}28.20 \\
(7.63)\end{array}$ & $\begin{array}{l}20.80 \\
(5.63)\end{array}$ & 281.11 \\
\hline Potassium chlorate (VII) & $\mathrm{KClO}_{4}$ & $\begin{array}{c}48.00 \\
(12.99)\end{array}$ & $\begin{array}{l}75.00 \\
(20.30)\end{array}$ & $\begin{array}{l}27.00 \\
(7.31)\end{array}$ & 56.25 \\
\hline Aluminium (powder) & $\mathrm{Al}$ & $\begin{array}{c}53.00 \\
(14.34)\end{array}$ & $\begin{array}{l}60.00 \\
(16.24)\end{array}$ & $\begin{array}{c}7.00 \\
(1.89)\end{array}$ & 13.21 \\
\hline Aluminum (flakes) & $\mathrm{Al}$ & $\begin{array}{l}180.00 \\
(48.72)\end{array}$ & $\begin{array}{l}70.00 \\
(18.95)\end{array}$ & $\begin{array}{l}-110.00 \\
(-29.77)\end{array}$ & -61.11 \\
\hline $\begin{array}{c}\text { PAM } \\
\text { Al-Mg powder }(50 / 50)\end{array}$ & $\mathrm{Al} / \mathrm{Mg}$ & $\begin{array}{c}66.00 \\
(17.86)\end{array}$ & $\begin{array}{c}60.00 \\
(16.24)\end{array}$ & $\begin{array}{l}-6.00 \\
(-1.62)\end{array}$ & -9.09 \\
\hline Sulphur (ground) & S & $\begin{array}{c}3.00 \\
(0.81)\end{array}$ & $\begin{array}{c}8.00 \\
(2.16)\end{array}$ & $\begin{array}{c}5.00 \\
(1.35)\end{array}$ & 166.33 \\
\hline
\end{tabular}

Concerning all of the analysed raw materials, the highest cost fluctuations could be observed for barium nitrate(V). In 1981, among all of the analysed components, it was one of the cheapest (cheaper only were sulphur and iron(III) oxide). Its current price has increased by PLN 52.30 (USD 14.15) which is an increase of about 333\%. As this oxidant is used as the main component for the manufacturing of the reference composition (M-0), a significant increase in the final price of this pyrotechnic composition should be expected in 2021. The price of iron(III) oxide has also increased significantly-from PLN 7.40 (USD 2.0) to PLN 28.20 (USD 7.63), a difference of PLN 20.80 (USD 5.63) and a price increase of about $281 \%$. This component is used as a second oxidant for both M-1 and M-2 compositions in amounts ranging from $5-25 \%$ (group 1) and $10-30 \%$ (group 2). For potassium chlorate (VII), a price increase of PLN 27 (USD 7.31) was recorded, which translates into a relatively low (compared to the components described so far) price increase of about $56 \%$. Similarly, the price of aluminium powder slightly increased by PLN 7 (USD 1.89) which, compared to the initial price, is an increase of only about $13 \%$. The only component that can be bought more cheaply compared to its 1981 value is aluminium (in the form of flakes) which, at that time, cost PLN 180 (USD 48.72) per $1 \mathrm{~kg}(2.20 \mathrm{lb})$ of raw material, and can now be purchased for about PLN 70 (USD18.95). Its price was reduced by approximately $61 \%$. The content of aluminium used to produce M-1 compositions is between $15 \%$ and $35 \%$ and the cost of this additive will therefore significantly influence the final price of pyrotechnic compositions in this group. The significant difference in the price of aluminium associated 
with its form largely determined the choice of its powder form in 1981. Today, the prices of aluminium powder and flakes are similar, and the choice of the form of this ingredient shall be considered from a technological point of view. There was little change in the price of PAM. A decrease of PLN 6 (USD 1.62) was observed, which translates into a 9\% decrease from the initial price. Despite a significant percentage price increase for ground sulphur of approx. 166\%, its price only increased from PLN 5 (USD 1.35) to PLN 8 (USD 2.16). Although this component is used in the manufacturing of all pyrotechnic compositions in large amounts, ranging from 15 to $35 \%$ due to its price being significantly lower than the other components, the increase in the price of this component will not significantly affect the final cost of producing pyrotechnic compositions. Both in 1981 and today, it remains the cheapest component used in the manufacture of pyrotechnic compositions.

\section{Changes in the Unit Price of Prospective Pyrotechnic Compositions}

For the variation ranges (assumed in Part I of the publication) given in Table 4, comparative cost curves showing the differences in prices (for 1981 and 2021) of individual pyrotechnic compositions depending on their chemical composition were determined in Figures 1-6. The tri-base graph method was used to present the results.

Table 4. Variation range for individual components [16].

\begin{tabular}{cccccc}
\hline \multirow{2}{*}{ Designation } & \multicolumn{5}{c}{ Variation Limits for Individual Components (\%) } \\
\cline { 2 - 6 } & $\mathbf{K C l O}_{4}$ & $\mathbf{F e}_{\mathbf{2}} \mathbf{O}$ & PAM & A1 & $\mathbf{S}$ \\
\hline Group 1 & $25-45$ & $25-5$ & - & $35-15$ & $15-35$ \\
\hline Group 2 & $20-40$ & $30-10$ & $30-20$ & - & $20-30$ \\
\hline
\end{tabular}

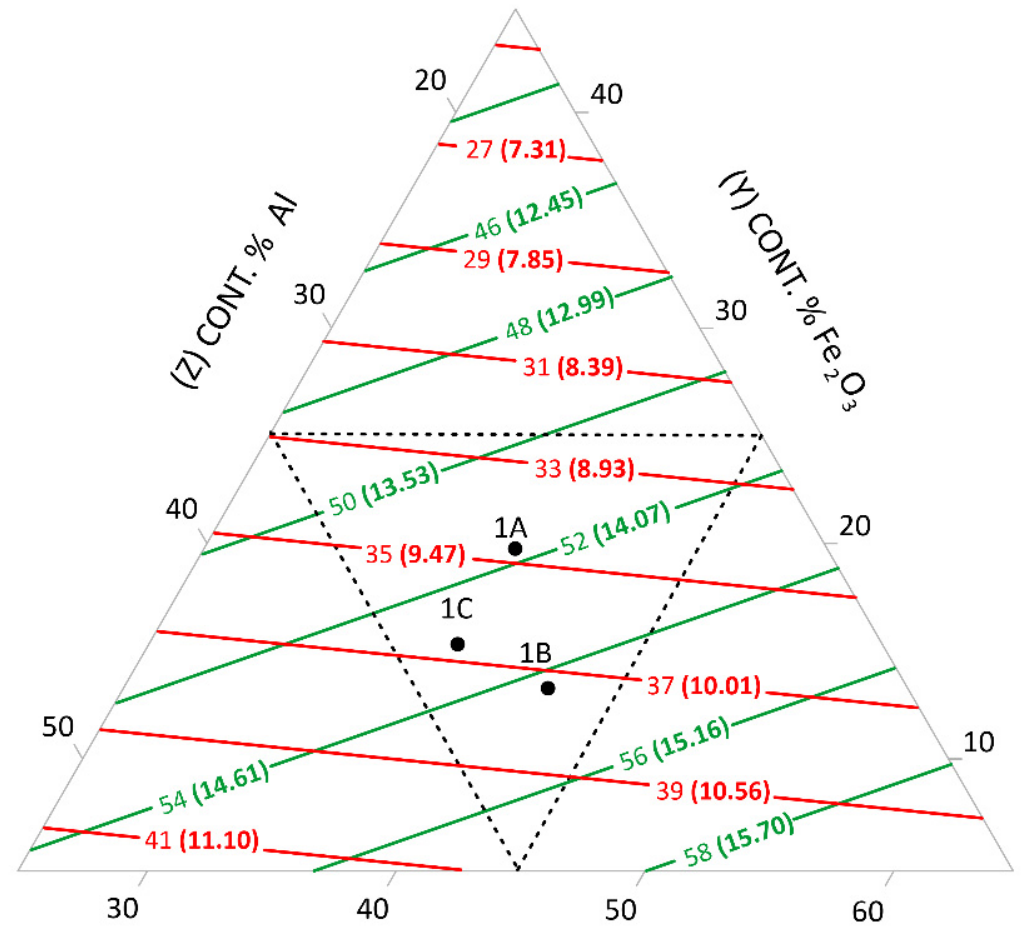

(X) CONT. \% $\mathrm{KClO}_{4}$

Figure 1. Relationship between costs of the composition (USD/kg): red line-1981, green line-2021; and the content of pyrotechnic composition components (\%). Sides of the triangle, with fixed sulphur content $\mathrm{S}=15 \%$. 


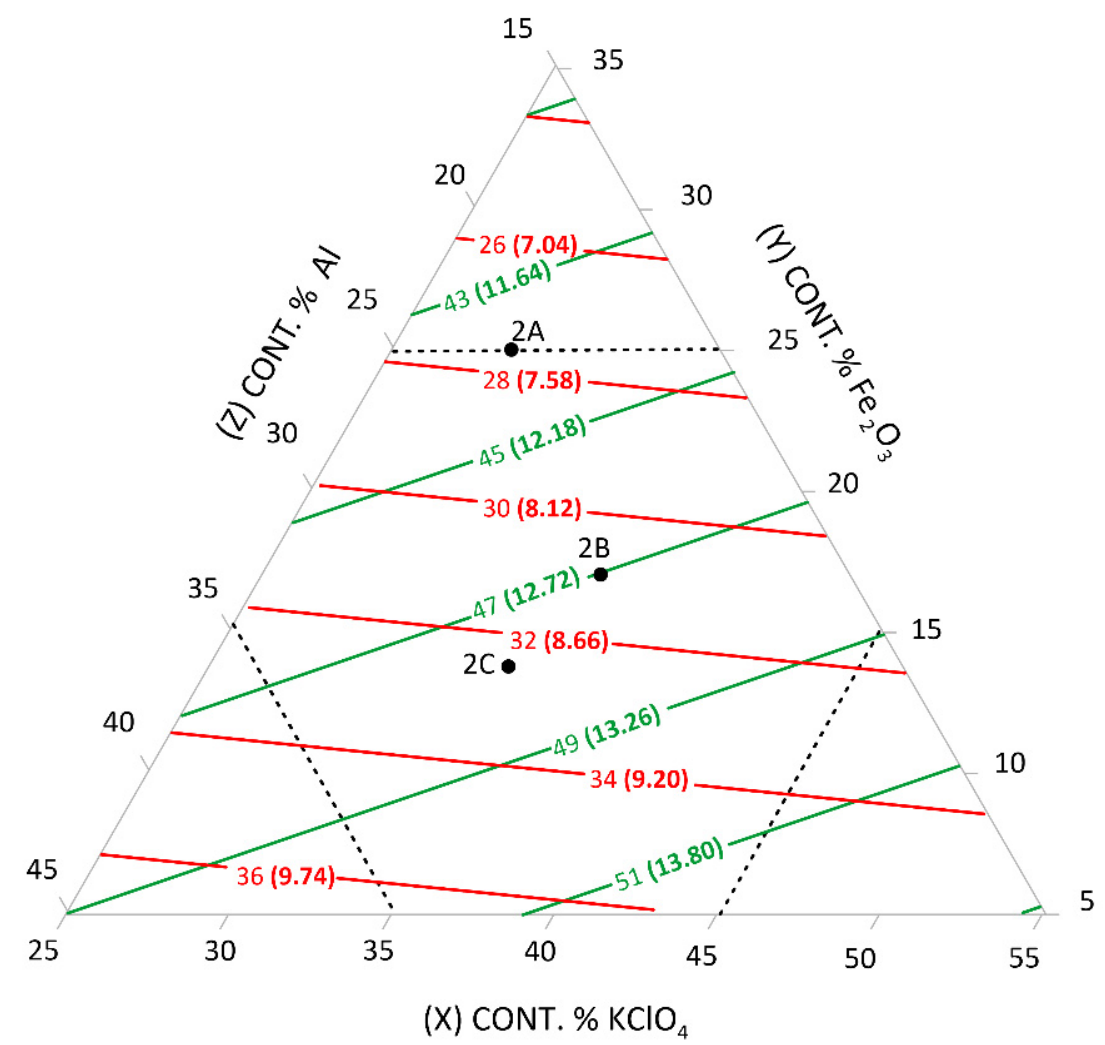

Figure 2. Relationship between costs of the composition (USD/kg): red line-1981, green line—2021; and the content of pyrotechnic composition components (\%). Sides of the triangle, with fixed sulphur content $\mathrm{S}=25 \%$.

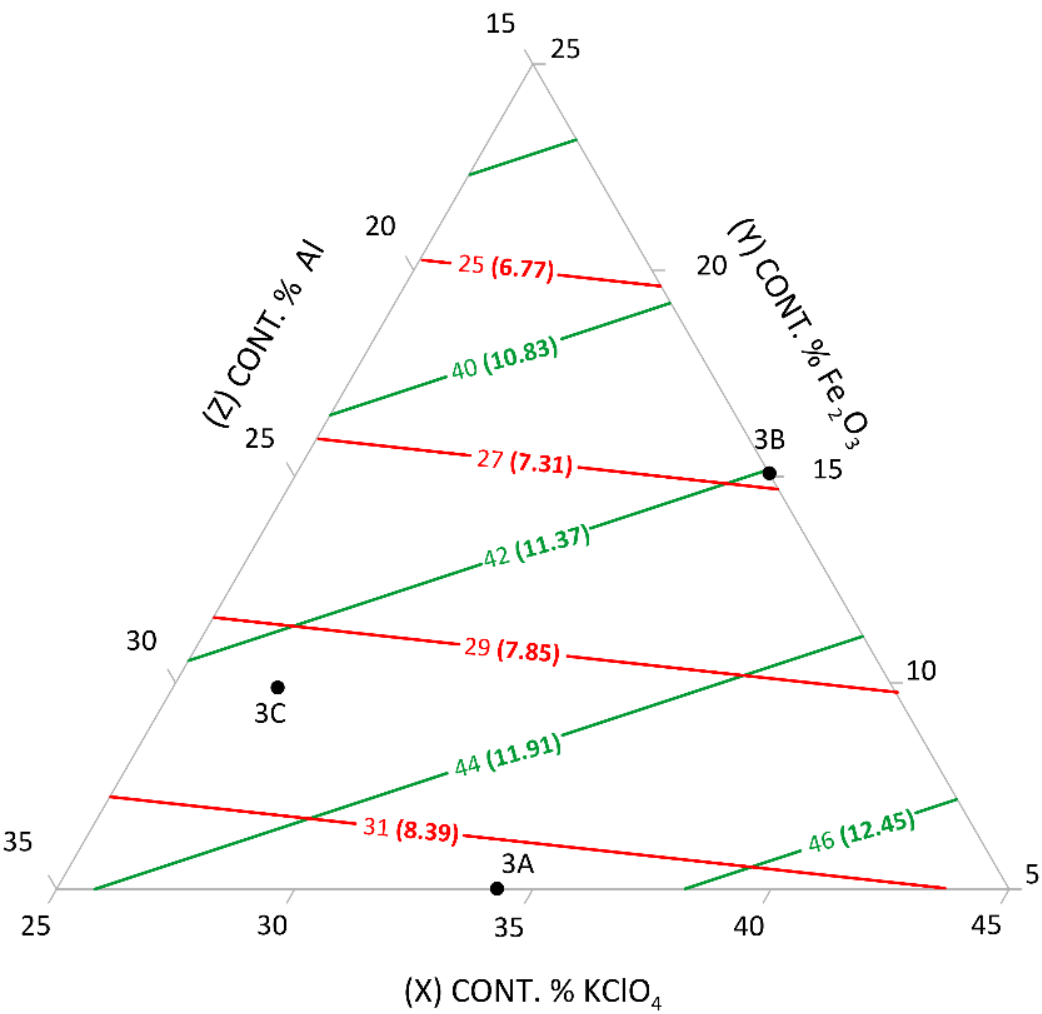

Figure 3. Relationship between costs of the composition (USD/kg): red line-1981, green line—2021; and the content of pyrotechnic composition components (\%). Sides of the triangle, with fixed sulphur content $\mathrm{S}=35 \%$. 


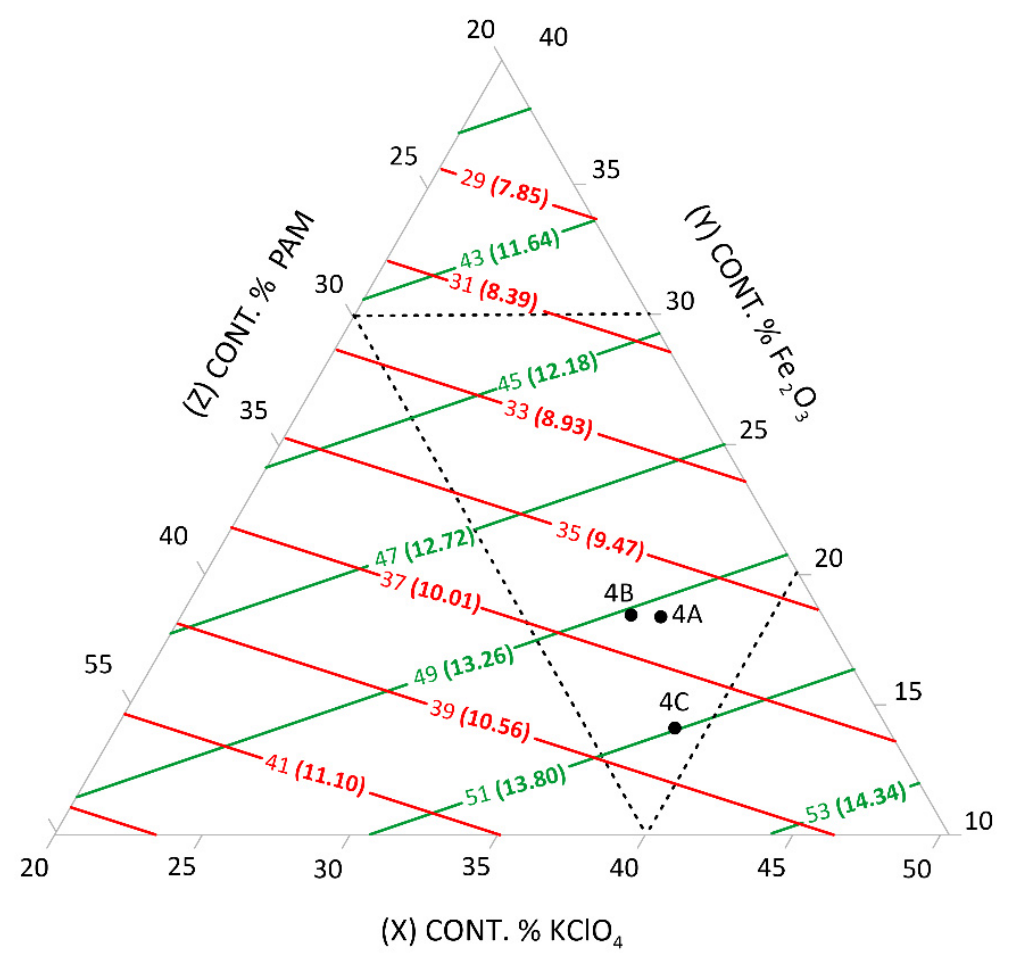

Figure 4. Relationship between costs of the composition (USD/kg): red line-1981, green line-2021; and the content of pyrotechnic composition components (\%). Sides of the triangle, with fixed sulphur content $S=20 \%$.

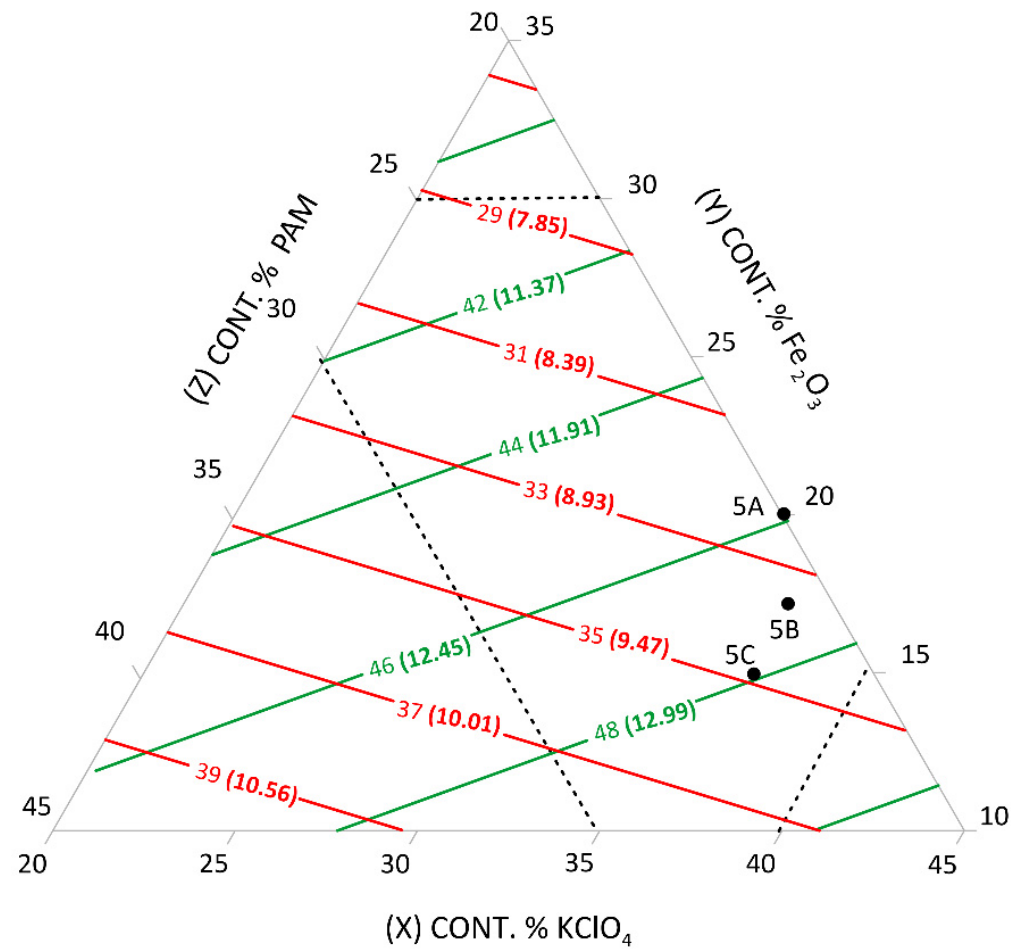

Figure 5. Relationship between costs of the composition (USD/kg): red line-1981, green line—2021; and the content of pyrotechnic composition components (\%). Sides of the triangle, with fixed sulphur content $\mathrm{S}=25 \%$. 


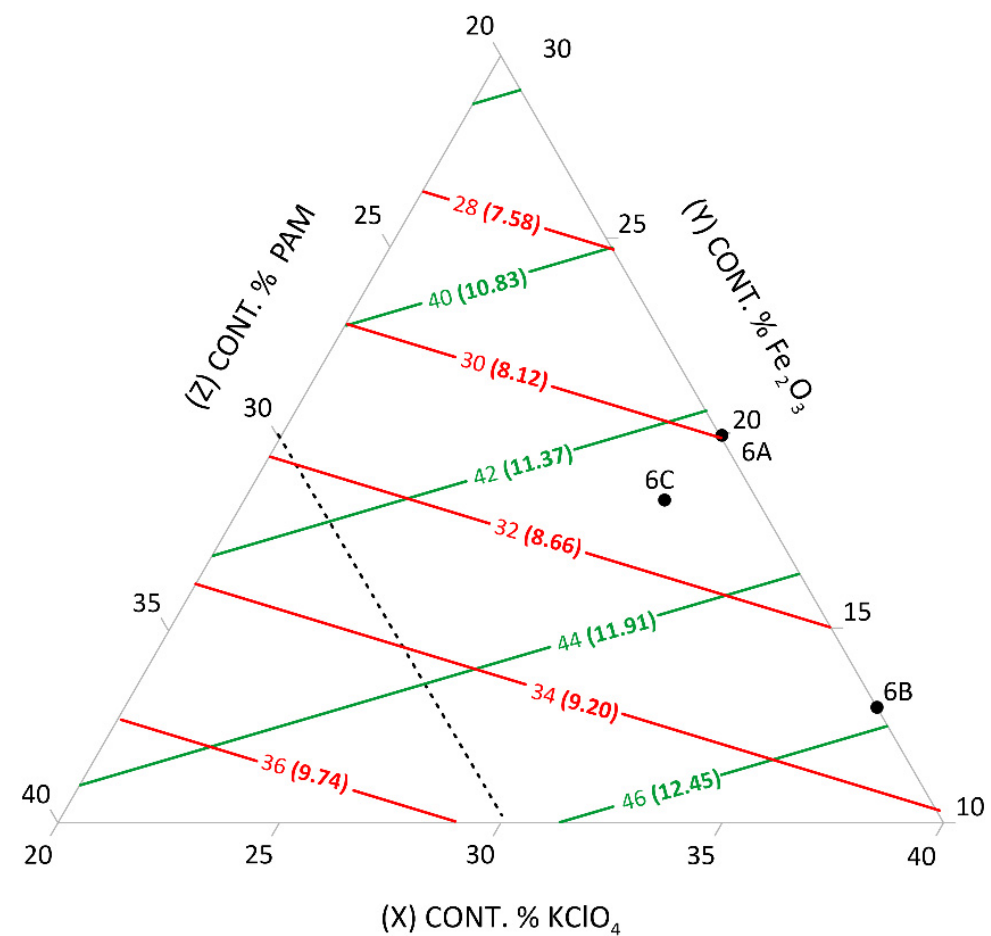

Figure 6. Relationship between costs of the composition (USD/kg): red line-1981, green line-2021; and the content of pyrotechnic composition components (\%). Sides of the triangle, with fixed sulphur content $\mathrm{S}=30 \%$.

Using triangular graphs, the cost of manufacturing three-component pyrotechnic composition can be determined based on the percentage of each group of components. Triangular graphs also make it possible to present the costs of manufacturing a pyrotechnic 4-component composition when the content of one of the components is constant (in the case of the presented pyrotechnic compositions, sulfur-S). The determined cost lines allow for a quicker reading of this data and an evaluation of the economic viability of particular pyrotechnic compositions depending on their chemical composition. It is also possible to determine cost ranges by determining the cost of the cheapest and the most expensive pyrotechnic composition. A summary of the lowest and highest cost of individual groups of pyrotechnic compositions is presented in Tables 5 and 6.

Table 5. A summary of the lowest and highest cost of pyrotechnic compositions from the M-1 group.

\begin{tabular}{|c|c|c|c|c|c|c|c|c|}
\hline \multirow[b]{2}{*}{ Figure Number } & \multicolumn{4}{|c|}{ Chemical Composition (\%) } & \multicolumn{4}{|c|}{ Unit Price PLN/kg (USD/kg) } \\
\hline & $\mathrm{KClO}_{4}$ & $\mathrm{Fe}_{2} \mathrm{O}_{3}$ & $\mathrm{Al}$ * & $\mathbf{S}$ & $\begin{array}{l}\text { Min. } \\
\text { (1981) }\end{array}$ & $\begin{array}{c}\text { Min. } \\
(2021)\end{array}$ & $\begin{array}{l}\text { Max. } \\
\text { (1981) }\end{array}$ & $\begin{array}{l}\text { Max. } \\
(2021)\end{array}$ \\
\hline \multirow{2}{*}{ Figure 1} & 25 & 45 & 15 & 15 & $\begin{array}{l}23.73 \\
(6.42)\end{array}$ & $\begin{array}{c}41.64 \\
(11.27)\end{array}$ & - & - \\
\hline & 25 & 5 & 55 & 15 & - & - & $\begin{array}{c}41.97 \\
(11.36)\end{array}$ & $\begin{array}{c}60.36 \\
(16.34)\end{array}$ \\
\hline \multirow{2}{*}{ Figure 2} & 25 & 35 & 15 & 25 & $\begin{array}{l}23.29 \\
(6.30)\end{array}$ & $\begin{array}{c}39.62 \\
(10.72)\end{array}$ & - & - \\
\hline & 25 & 5 & 45 & 25 & - & - & $\begin{array}{c}36.97 \\
(10.01)\end{array}$ & $\begin{array}{c}49.16 \\
(13.30)\end{array}$ \\
\hline \multirow{2}{*}{ Figure 3} & 25 & 25 & 15 & 35 & $\begin{array}{l}22.85 \\
(6.18)\end{array}$ & $\begin{array}{c}37.60 \\
(10.18)\end{array}$ & - & - \\
\hline & 25 & 5 & 35 & 35 & - & - & $\begin{array}{l}31.97 \\
(8.65)\end{array}$ & $\begin{array}{c}46.96 \\
(12.71)\end{array}$ \\
\hline
\end{tabular}

* Assumed prices for aluminium powder. 
Table 6. A summary of the lowest and highest cost of pyrotechnic compositions from the M-1 group.

\begin{tabular}{|c|c|c|c|c|c|c|c|c|}
\hline \multirow[b]{2}{*}{ Figure Number } & \multicolumn{4}{|c|}{ Chemical Composition (\%) } & \multicolumn{4}{|c|}{ Unit Price PLN/kg (USD/kg) } \\
\hline & $\mathrm{KClO}_{4}$ & $\mathrm{Fe}_{2} \mathrm{O}_{3}$ & PAM & $S$ & $\begin{array}{l}\text { Min. } \\
\text { (1981) }\end{array}$ & $\begin{array}{l}\text { Min. } \\
\text { (2021) }\end{array}$ & $\begin{array}{r}\text { Max. } \\
\text { (1981) }\end{array}$ & $\begin{array}{l}\text { Max. } \\
\text { (2021) }\end{array}$ \\
\hline \multirow{2}{*}{ Figure 4} & 20 & 40 & 20 & 20 & $\begin{array}{l}26.36 \\
(7.13)\end{array}$ & $\begin{array}{c}38.88 \\
(10.79)\end{array}$ & - & - \\
\hline & 20 & 10 & 50 & 20 & - & - & $\begin{array}{c}43.94 \\
(11.89)\end{array}$ & $\begin{array}{c}53.92 \\
(14.59)\end{array}$ \\
\hline \multirow{2}{*}{ Figure 5} & 20 & 35 & 20 & 25 & $\begin{array}{l}26.14 \\
(7.07)\end{array}$ & $\begin{array}{c}38.87 \\
(10.52)\end{array}$ & - & - \\
\hline & 20 & 10 & 45 & 25 & - & - & $\begin{array}{c}40.79 \\
(11.04)\end{array}$ & $\begin{array}{c}50.57 \\
(13.69)\end{array}$ \\
\hline \multirow{2}{*}{ Figure 6} & 20 & 30 & 20 & 30 & $\begin{array}{l}25.92 \\
(7.02)\end{array}$ & $\begin{array}{c}37.86 \\
(10.25)\end{array}$ & - & - \\
\hline & 20 & 10 & 40 & 30 & - & - & $\begin{array}{c}37.64 \\
(10.19)\end{array}$ & $\begin{array}{c}47.22 \\
(12.78)\end{array}$ \\
\hline
\end{tabular}

From the M-1 group, the lowest unit cost is for the composition made of: $\mathrm{KClO}_{4}-25 \%$, $\mathrm{Fe}_{2} \mathrm{O}_{3}-25 \%, \mathrm{Al}-15 \%$, $\mathrm{S}-35 \%$ and is PLN 37.60 (USD 10.18). The most expensive composition is the one made of: $\mathrm{KClO}_{4}-25 \%, \mathrm{Fe}_{2} \mathrm{O}_{3}-5 \%$, Al-55\%, S-15\%, $1 \mathrm{~kg}$ of which costs PLN 60.36 (USD 16.34).

In the case of the triangular graphs for M-2 group compositions, one might see that the lowest unit cost was characteristic for the composition made of: $\mathrm{ClO}_{4}-20 \%, \mathrm{Fe}_{2} \mathrm{O}_{3}-30 \%$, aluminium-magnesium powder-20\% and S-30\%, which costs PLN 37.86 (USD 10.25). The most expensive composition was the one made of: $\mathrm{KClO}_{4}-20 \%, \mathrm{Fe}_{2} \mathrm{O}_{3}-10 \%, \mathrm{Al}-50 \%$, and S-20\%, a unit of which costs PLN53.92 (USD 14.59).

Based on the data concerning the prices of particular components in the years 1981 and 2021, the unit costs of manufacturing of individual prospective pyrotechnic compositions were calculated. Calculations for compositions from the M-1 group are presented in Table 7, and for the M-2 group in Table 8.

Table 7. Analysis of changes in unit prices of pyrotechnic compositions from the M-1 group and the M-0 comparison group.

\begin{tabular}{|c|c|c|c|c|c|c|c|c|}
\hline \multirow{2}{*}{ Designation } & \multicolumn{4}{|c|}{ Chemical Composition (\%) } & \multirow{2}{*}{$\begin{array}{l}\text { Unit Price } \\
\text { (1981) PLN/kg } \\
\text { (USD/kg) }\end{array}$} & \multirow{2}{*}{$\begin{array}{c}\text { Unit Price (2021) } \\
\text { PLN/kg } \\
\text { (USD/kg) }\end{array}$} & \multirow{2}{*}{$\begin{array}{l}\text { Price Difference Compared to } \\
1981 \text { PLN/kg } \\
\text { (USD/kg) }\end{array}$} & \multirow{2}{*}{$\begin{array}{c}\text { Price Difference } \\
\text { Compared to } 1981(\%)\end{array}$} \\
\hline & $\mathrm{Ba}\left(\mathrm{NO}_{3}\right.$ & & PAM & S & & & & \\
\hline M-0 & 64 & & 18 & 18 & $\begin{array}{l}22.47 \\
(6.08) \\
\end{array}$ & $\begin{array}{c}55.76 \\
(15.09) \\
\end{array}$ & $\begin{array}{l}33.29 \\
(9.01) \\
\end{array}$ & 148.17 \\
\hline \multirow{2}{*}{ Designation } & \multicolumn{4}{|c|}{ Chemical Composition (\%) } & Unit Price & Unit Price (2021) & Price Difference Compared to & Price Difference \\
\hline & $\mathrm{KClO}_{4}$ & $\mathrm{Fe}_{2} \mathrm{O}_{3}$ & $\mathbf{A l}$ * & S & (USD/kg) & (USD/kg) & (USD/kg) & Compared to $1981(\%)$ \\
\hline $1 \mathrm{~A}$ & 38 & 19 & 28 & 15 & $\begin{array}{l}34.94 \\
(9.46)\end{array}$ & $\begin{array}{c}51.86 \\
(14.03)\end{array}$ & $\begin{array}{l}16.92 \\
(4.58)\end{array}$ & 48.43 \\
\hline $1 \mathrm{~B}$ & 42 & 13 & 30 & 15 & $\begin{array}{c}37.47 \\
(10.14)\end{array}$ & $\begin{array}{c}54.36 \\
(14.71)\end{array}$ & $\begin{array}{l}16.89 \\
(4.57)\end{array}$ & 45.08 \\
\hline $1 C$ & 38 & 15 & 32 & 15 & $\begin{array}{l}36.76 \\
(9.95)\end{array}$ & $\begin{array}{c}53.13 \\
(14.38)\end{array}$ & $\begin{array}{l}16.37 \\
(4.43)\end{array}$ & 44.53 \\
\hline $2 \mathrm{~A}$ & 30 & 25 & 20 & 25 & $\begin{array}{l}27.60 \\
(7.47)\end{array}$ & $\begin{array}{c}43.55 \\
(11.79)\end{array}$ & $\begin{array}{l}15.95 \\
(4.32)\end{array}$ & 57.78 \\
\hline $2 \mathrm{~B}$ & 36 & 17 & 22 & 25 & $\begin{array}{l}30.95 \\
(8.38)\end{array}$ & $\begin{array}{c}46.99 \\
(12.72)\end{array}$ & $\begin{array}{l}16.04 \\
(4.34)\end{array}$ & 51.84 \\
\hline $2 \mathrm{C}$ & 35 & 14 & 26 & 25 & $\begin{array}{l}32.37 \\
(8.76)\end{array}$ & $\begin{array}{c}47.80 \\
(12.94)\end{array}$ & $\begin{array}{l}15.43 \\
(4.18)\end{array}$ & 47.67 \\
\hline $3 \mathrm{~A}$ & 34 & 5 & 26 & 35 & $\begin{array}{l}31.52 \\
(8.53)\end{array}$ & $\begin{array}{c}45.31 \\
(12.26)\end{array}$ & $\begin{array}{l}13.79 \\
(3.73)\end{array}$ & 43.74 \\
\hline 3B & 35 & 15 & 15 & 35 & $\begin{array}{l}26.91 \\
(7.28)\end{array}$ & $\begin{array}{c}42.28 \\
(11.44)\end{array}$ & $\begin{array}{l}15.37 \\
(4.16) \\
\end{array}$ & 57.10 \\
\hline $3 C$ & 28 & 10 & 27 & 35 & $\begin{array}{l}29.54 \\
(7.99)\end{array}$ & $\begin{array}{c}42.82 \\
(11.59)\end{array}$ & $\begin{array}{l}13.28 \\
(3.59)\end{array}$ & 44.94 \\
\hline
\end{tabular}

* Assumed prices for aluminium powder. 
Table 8. Analysis of changes in unit prices of pyrotechnic compositions from M-2 group and M-0 comparison group.

\begin{tabular}{|c|c|c|c|c|c|c|c|c|}
\hline \multirow{2}{*}{ Designation } & \multicolumn{4}{|c|}{ Chemical Composition (\%) } & \multirow{2}{*}{$\begin{array}{l}\text { Unit Price } \\
\text { (1981) PLN/kg } \\
\text { (USD/kg) }\end{array}$} & \multirow{2}{*}{$\begin{array}{l}\text { Unit Price (2021) } \\
\text { PLN/kg } \\
\text { (USD/kg) }\end{array}$} & \multirow{2}{*}{$\begin{array}{c}\text { Price Difference Compared to } \\
1981 \text { PLN/kg } \\
\text { (USD } / \mathrm{kg} \text { ) }\end{array}$} & \multirow{2}{*}{$\begin{array}{c}\text { Price Difference } \\
\text { Compared to } \\
1981(\%)\end{array}$} \\
\hline & $\operatorname{Ba}(\mathbf{N}$ & $\left.\mathrm{O}_{3}\right)_{2}$ & PAM & $\mathrm{S}$ & & & & \\
\hline M-0 & 6 & & 18 & 18 & $\begin{array}{l}22.47 \\
(6.08)\end{array}$ & $\begin{array}{l}55.76 \\
(15.09)\end{array}$ & $\begin{array}{l}33.29 \\
(9.01)\end{array}$ & 148.17 \\
\hline \multirow{2}{*}{ Designation } & \multicolumn{4}{|c|}{ Chemical Composition (\%) } & Unit Price & Unit Price (2021) & Price Difference Compared to & Price Difference \\
\hline & $\mathrm{KClO}_{4}$ & $\mathrm{Fe}_{2} \mathrm{O}_{3}$ & PAM & $S$ & (USD/kg) & (USD/kg) & $\begin{array}{l}1981 \text { PLN/kg } \\
\text { (USD/kg) }\end{array}$ & $\begin{array}{c}\text { Compared to } \\
1981(\%)\end{array}$ \\
\hline $4 \mathrm{~A}$ & 36 & 18 & 26 & 20 & $\begin{array}{l}36.37 \\
(9.84)\end{array}$ & $\begin{array}{c}49.27 \\
(13.34)\end{array}$ & $\begin{array}{l}12.90 \\
(3.49)\end{array}$ & 35.47 \\
\hline $4 \mathrm{~B}$ & 35 & 18 & 27 & 20 & $\begin{array}{l}36.55 \\
(9.89)\end{array}$ & $\begin{array}{c}49.12 \\
(13.30)\end{array}$ & $\begin{array}{l}12.57 \\
(3.40)\end{array}$ & 34.40 \\
\hline $4 \mathrm{C}$ & 39 & 14 & 27 & 20 & $\begin{array}{c}38.18 \\
(10.33)\end{array}$ & $\begin{array}{c}51.00 \\
(13.80)\end{array}$ & $\begin{array}{l}12.82 \\
(3.47)\end{array}$ & 33.58 \\
\hline $5 \mathrm{~A}$ & 35 & 20 & 20 & 25 & $\begin{array}{l}32.23 \\
(8.72)\end{array}$ & $\begin{array}{c}45.89 \\
(12.42)\end{array}$ & $\begin{array}{l}13.66 \\
(3.70)\end{array}$ & 42.38 \\
\hline $5 B$ & 37 & 17 & 21 & 25 & $\begin{array}{l}33.63 \\
(9.10)\end{array}$ & $\begin{array}{c}47.14 \\
(12.76)\end{array}$ & $\begin{array}{l}13.51 \\
(3.66)\end{array}$ & 40.19 \\
\hline $5 \mathrm{C}$ & 38 & 15 & 22 & 25 & $\begin{array}{l}34.62 \\
(9.37)\end{array}$ & $\begin{array}{c}47.93 \\
(12.97)\end{array}$ & $\begin{array}{l}13.31 \\
(3.60)\end{array}$ & 38.44 \\
\hline $6 \mathrm{~A}$ & 30 & 20 & 20 & 30 & $\begin{array}{l}29.98 \\
(8.11)\end{array}$ & $\begin{array}{c}42.54 \\
(11.51)\end{array}$ & $\begin{array}{l}12.56 \\
(3.40)\end{array}$ & 41.89 \\
\hline $6 \mathrm{~B}$ & 37 & 13 & 20 & 30 & $\begin{array}{l}32.82 \\
(8.88)\end{array}$ & $\begin{array}{c}45.81 \\
(12.40)\end{array}$ & $\begin{array}{l}12.99 \\
(3.52)\end{array}$ & 39.58 \\
\hline $6 \mathrm{C}$ & 29 & 18 & 23 & 30 & $\begin{array}{l}31.33 \\
(8.48)\end{array}$ & $\begin{array}{c}43.02 \\
(11.64)\end{array}$ & $\begin{array}{l}11.69 \\
(3.16)\end{array}$ & 37.31 \\
\hline
\end{tabular}

A significant increase in the price of barium nitrate $(\mathrm{V})$, the main component of the pyrotechnic comparison composition, increased the cost of manufacturing the M- 0 group. Since the oxidant constitutes $64 \%$ of this composition by weight, the cost of manufacturing this composition increased from PLN 22.47 (USD 6.08) in 1981 to PLN 55.76 (USD 14.03) in 2021, by PLN 33.29 (USD 9.01), which is approximately $148 \%$ higher than the original price. Since almost all groups of components of pyrotechnic compositions became more expensive, the cost of manufacturing all compositions from the M-1 group increased on average by approximately PLN 15.56 (USD 4.21). In contrast, the average percentage increase in cost was approximately $49 \%$. Despite this, in 2021, all compositions from the $\mathrm{M}-1$ group were cheaper compared to M-0 compositions. The cheapest was, and remains, composition 3B (PLN 25.91/USD 7.28 in 1981 and PLN 42.28/USD 11.44 in 2021). The highest manufacturing costs were calculated for composition 1B (PLN 37.47/USD 10.14 in 1981 and PLN 54.36/USD 14.03 in 2021).

The total unit cost of the components of all pyrotechnic compositions from the M-2 group is now also lower compared to the M-0 group and ranges from PLN 42.54-51.00 (USD 11.51-13.80). The average value of the price difference concerning this group was PLN 12.89 (USD 3.49) and expressing the difference in percentage, the increase was calculated at $38.14 \%$. The cheapest composition to make is the 6A (PLN 29.98/USD 8.11 in 1981 and PLN 42.54/USD 11.51 in 2021). On the other hand, the highest cost was calculated for 4C (PLN 38.18/USD 10.33 in 1981 and PLN 51.00/USD 13.80 in 2021).

\section{Manufacturing Costs of Pyrotechnic Compositions in Large Amounts}

On the basis of fluctuations of the unit cost of manufacturing individual pyrotechnic compositions, the influence of these values concerning the manufacturing conditions was evaluated.

For this purpose, two models were distinguished for which the following assumptions were made:

- $\quad$ Model 1 production batch of $500 \mathrm{~kg}$ (1102 lb) of pyrotechnic composition;

- $\quad$ Model 2 production batch of $2000 \mathrm{~kg}(4409 \mathrm{lb})$ of pyrotechnic composition.

The modelling results are presented in Tables 9-12. To simplify the recording of the results, the prices have been rounded to the nearest whole value according to the theory of approximation. 
Table 9. Comparison of manufacturing costs of pyrotechnic compositions from the M-1 group for model 1, batch of $500 \mathrm{~kg}$ (1102 lb) of pyrotechnic compositions.

\begin{tabular}{|c|c|c|c|c|c|c|c|}
\hline \multirow{2}{*}{ Designation } & \multicolumn{4}{|c|}{ Chemical Composition (\%) } & \multirow{2}{*}{$\begin{array}{l}\text { Price } \\
\text { (1981) } \\
\text { PLN } \\
\text { (USD) }\end{array}$} & \multirow{2}{*}{$\begin{array}{l}\text { Price } \\
(2021) \\
\text { PLN } \\
\text { (USD) }\end{array}$} & \multirow{2}{*}{$\begin{array}{c}\text { Price Difference Compared } \\
\text { to } 1981 \text { PLN } \\
\text { (USD) }\end{array}$} \\
\hline & \multicolumn{2}{|c|}{$\mathrm{Ba}\left(\mathrm{NO}_{3}\right)_{2}$} & PAM & $\mathrm{S}$ & & & \\
\hline M-0 & \multicolumn{2}{|c|}{64} & 18 & 18 & $\begin{array}{l}11,234 \\
(3040)\end{array}$ & $\begin{array}{l}27,879 \\
(7545)\end{array}$ & $\begin{array}{l}16,645 \\
(4505)\end{array}$ \\
\hline \multirow[t]{2}{*}{ Designation } & \multicolumn{4}{|c|}{ Chemical Composition (\%) } & $\begin{array}{l}\text { Price } \\
\text { (1981) }\end{array}$ & $\begin{array}{l}\text { Price } \\
(2021)\end{array}$ & Price Difference Compared \\
\hline & $\mathrm{KClO}_{4}$ & $\mathrm{Fe}_{2} \mathrm{O}_{3}$ & Al & $\mathrm{S}$ & $\begin{array}{l}\text { PLN } \\
\text { (USD) }\end{array}$ & $\begin{array}{l}\text { PLN } \\
\text { (USD) }\end{array}$ & (USD) \\
\hline $1 \mathrm{~A}$ & 38 & 19 & 28 & 15 & $\begin{array}{l}17,468 \\
(4728)\end{array}$ & $\begin{array}{l}25,928 \\
(7017)\end{array}$ & $\begin{array}{c}8460 \\
(2290)\end{array}$ \\
\hline 1B & 42 & 13 & 30 & 15 & $\begin{array}{l}18,736 \\
(5071)\end{array}$ & $\begin{array}{l}27,182 \\
(7357)\end{array}$ & $\begin{array}{c}8446 \\
(2286)\end{array}$ \\
\hline $1 C$ & 38 & 15 & 32 & 15 & $\begin{array}{l}18,380 \\
(4974)\end{array}$ & $\begin{array}{l}26,564 \\
(7189)\end{array}$ & $\begin{array}{c}8184 \\
(2215)\end{array}$ \\
\hline $2 \mathrm{~A}$ & 30 & 25 & 20 & 25 & $\begin{array}{l}13,800 \\
(3735)\end{array}$ & $\begin{array}{l}21,774 \\
(5893)\end{array}$ & $\begin{array}{c}7974 \\
(2158)\end{array}$ \\
\hline $2 B$ & 36 & 17 & 22 & 25 & $\begin{array}{l}15,474 \\
(4188)\end{array}$ & $\begin{array}{l}23,496 \\
(6359)\end{array}$ & $\begin{array}{c}8022 \\
(2171)\end{array}$ \\
\hline $2 \mathrm{C}$ & 35 & 14 & 26 & 25 & $\begin{array}{l}16,183 \\
(4380)\end{array}$ & $\begin{array}{l}23,898 \\
(6468)\end{array}$ & $\begin{array}{c}7715 \\
(2088)\end{array}$ \\
\hline $3 \mathrm{~A}$ & 34 & 5 & 26 & 35 & $\begin{array}{l}15,760 \\
(4265)\end{array}$ & $\begin{array}{l}22,653 \\
(6131)\end{array}$ & $\begin{array}{c}6893 \\
(1866)\end{array}$ \\
\hline 3B & 35 & 15 & 15 & 35 & $\begin{array}{l}13,455 \\
(3642)\end{array}$ & $\begin{array}{l}21,138 \\
(5721)\end{array}$ & $\begin{array}{c}7683 \\
(2079)\end{array}$ \\
\hline $3 C$ & 28 & 10 & 27 & 35 & $\begin{array}{l}14,770 \\
(3997)\end{array}$ & $\begin{array}{l}21,408 \\
(5794)\end{array}$ & $\begin{array}{c}6638 \\
(1797)\end{array}$ \\
\hline
\end{tabular}

Table 10. Comparison of manufacturing costs of pyrotechnic compositions from the M-2 group for model 1, batch of $500 \mathrm{~kg}$ (1102 lb) of pyrotechnic compositions.

\begin{tabular}{|c|c|c|c|c|c|c|c|}
\hline \multirow{2}{*}{ Designation } & \multicolumn{4}{|c|}{ Chemical Composition (\%) } & \multirow{2}{*}{$\begin{array}{l}\text { Price } \\
\text { (1981) } \\
\text { PLN } \\
\text { (USD) }\end{array}$} & \multirow{2}{*}{$\begin{array}{l}\text { Price } \\
(2021) \\
\text { PLN } \\
\text { (USD) }\end{array}$} & \multirow{2}{*}{$\begin{array}{c}\text { Price Difference Compared } \\
\text { to } 1981 \text { PLN } \\
\text { (USD) }\end{array}$} \\
\hline & \multicolumn{2}{|c|}{$\mathrm{Ba}\left(\mathrm{NO}_{3}\right)_{2}$} & PAM & $S$ & & & \\
\hline M-0 & \multicolumn{2}{|c|}{64} & 18 & 18 & $\begin{array}{l}11,234 \\
(3040)\end{array}$ & $\begin{array}{l}27,879 \\
(7545)\end{array}$ & $\begin{array}{l}16,645 \\
(4505)\end{array}$ \\
\hline \multirow[t]{2}{*}{ Designation } & \multicolumn{4}{|c|}{ Chemical Composition (\%) } & $\begin{array}{l}\text { Price } \\
\text { (1981) }\end{array}$ & $\begin{array}{l}\text { Price } \\
(2021)\end{array}$ & $\begin{array}{c}\text { Price Difference Compared } \\
\text { to } 1981 \text { PLN }\end{array}$ \\
\hline & $\mathrm{KClO}_{4}$ & $\mathrm{Fe}_{2} \mathrm{O}_{3}$ & Al & $S$ & (USD) & (USD) & (USD) \\
\hline $4 \mathrm{~A}$ & 36 & 18 & 26 & 20 & $\begin{array}{l}18,186 \\
(4922)\end{array}$ & $\begin{array}{l}24,637 \\
(6668)\end{array}$ & $\begin{array}{c}6451 \\
(1746)\end{array}$ \\
\hline $4 \mathrm{~B}$ & 35 & 18 & 27 & 20 & $\begin{array}{l}18,276 \\
(4946)\end{array}$ & $\begin{array}{l}24,562 \\
(6648)\end{array}$ & $\begin{array}{c}6286 \\
(1701)\end{array}$ \\
\hline $4 \mathrm{C}$ & 39 & 14 & 27 & 20 & $\begin{array}{l}19,088 \\
(5166)\end{array}$ & $\begin{array}{l}25,498 \\
(6901)\end{array}$ & $\begin{array}{c}6410 \\
(1735)\end{array}$ \\
\hline $5 \mathrm{~A}$ & 35 & 20 & 20 & 25 & $\begin{array}{l}16,115 \\
(4361)\end{array}$ & $\begin{array}{l}22,944 \\
(6210)\end{array}$ & $\begin{array}{c}6829 \\
(1848)\end{array}$ \\
\hline $5 \mathrm{~B}$ & 37 & 17 & 21 & 25 & $\begin{array}{l}16,814 \\
(4551)\end{array}$ & $\begin{array}{l}23,571 \\
(6379)\end{array}$ & $\begin{array}{c}6757 \\
(1829)\end{array}$ \\
\hline $5 \mathrm{C}$ & 38 & 15 & 22 & 25 & $\begin{array}{l}17,310 \\
(4685)\end{array}$ & $\begin{array}{l}23,964 \\
(6486)\end{array}$ & $\begin{array}{c}6654 \\
(1801)\end{array}$ \\
\hline $6 \mathrm{~A}$ & 30 & 20 & 20 & 30 & $\begin{array}{l}14,990 \\
(4057)\end{array}$ & $\begin{array}{l}21,269 \\
(5756)\end{array}$ & $\begin{array}{c}6279 \\
(1699)\end{array}$ \\
\hline $6 \mathrm{~B}$ & 37 & 13 & 20 & 30 & $\begin{array}{l}16,411 \\
(4442)\end{array}$ & $\begin{array}{l}22,907 \\
(6200)\end{array}$ & $\begin{array}{c}6496 \\
(1758)\end{array}$ \\
\hline $6 \mathrm{C}$ & 29 & 18 & 23 & 30 & $\begin{array}{l}15,666 \\
(4240)\end{array}$ & $\begin{array}{l}21,512 \\
(5822)\end{array}$ & $\begin{array}{c}5846 \\
(1582)\end{array}$ \\
\hline
\end{tabular}


Table 11. Comparison of manufacturing costs of pyrotechnic compositions from the M-1 group for model 1, batch of $2000 \mathrm{~kg}$ (4409 lb) of pyrotechnic compositions.

\begin{tabular}{|c|c|c|c|c|c|c|c|}
\hline \multirow{2}{*}{ Designation } & \multicolumn{4}{|c|}{ Chemical Composition (\%) } & \multirow{2}{*}{$\begin{array}{l}\text { Price } \\
\text { (1981) } \\
\text { PLN } \\
\text { (USD) }\end{array}$} & \multirow{2}{*}{$\begin{array}{l}\text { Price } \\
(2021) \\
\text { PLN } \\
\text { (USD) }\end{array}$} & \multirow{2}{*}{$\begin{array}{c}\text { Price Difference Compared } \\
\text { to 1981 PLN } \\
\text { (USD) }\end{array}$} \\
\hline & \multicolumn{2}{|c|}{$\mathrm{Ba}\left(\mathrm{NO}_{3}\right)_{2}$} & PAM & $\mathrm{S}$ & & & \\
\hline M-0 & \multicolumn{2}{|c|}{64} & 18 & 18 & $\begin{array}{c}44,936 \\
(12,162)\end{array}$ & $\begin{array}{l}111,518 \\
(30,182)\end{array}$ & $\begin{array}{c}66,582 \\
(18,020)\end{array}$ \\
\hline \multirow[t]{2}{*}{ Designation } & \multicolumn{4}{|c|}{ Chemical Composition (\%) } & $\begin{array}{l}\text { Price } \\
\text { (1981) }\end{array}$ & $\begin{array}{l}\text { Price } \\
(2021)\end{array}$ & $\begin{array}{c}\text { Price Difference Compared } \\
\text { to } 1981 \text { PLN }\end{array}$ \\
\hline & $\mathrm{KClO}_{4}$ & $\mathrm{Fe}_{2} \mathrm{O}_{3}$ & Al & $\mathrm{S}$ & (USD) & (USD) & (USD) \\
\hline $1 \mathrm{~A}$ & 38 & 19 & 28 & 15 & $\begin{array}{c}69,872 \\
(18,910)\end{array}$ & $\begin{array}{c}103,714 \\
(28,069)\end{array}$ & $\begin{array}{l}33,842 \\
(9159)\end{array}$ \\
\hline 1B & 42 & 13 & 30 & 15 & $\begin{array}{c}74,944 \\
(20,283)\end{array}$ & $\begin{array}{l}108,730 \\
(29,427)\end{array}$ & $\begin{array}{l}33,786 \\
(9144)\end{array}$ \\
\hline $1 \mathrm{C}$ & 38 & 15 & 32 & 15 & $\begin{array}{c}73,520 \\
(19,898)\end{array}$ & $\begin{array}{l}106,258 \\
(28,758)\end{array}$ & $\begin{array}{l}32,738 \\
(8860)\end{array}$ \\
\hline $2 \mathrm{~A}$ & 30 & 25 & 20 & 25 & $\begin{array}{c}55,200 \\
(14,940)\end{array}$ & $\begin{array}{c}87,096 \\
(23,572)\end{array}$ & $\begin{array}{l}31,896 \\
(8632)\end{array}$ \\
\hline $2 \mathrm{~B}$ & 36 & 17 & 22 & 25 & $\begin{array}{c}61,896 \\
(16,752)\end{array}$ & $\begin{array}{c}93,984 \\
(25,436)\end{array}$ & $\begin{array}{l}32,088 \\
(8684)\end{array}$ \\
\hline $2 \mathrm{C}$ & 35 & 14 & 26 & 25 & $\begin{array}{c}64,732 \\
(17,519)\end{array}$ & $\begin{array}{c}95,592 \\
(25,871)\end{array}$ & $\begin{array}{l}30,860 \\
(8352)\end{array}$ \\
\hline $3 \mathrm{~A}$ & 34 & 5 & 26 & 35 & $\begin{array}{c}63,040 \\
(17,061)\end{array}$ & $\begin{array}{c}90,613 \\
(24,524)\end{array}$ & $\begin{array}{l}27,573 \\
(7463)\end{array}$ \\
\hline $3 B$ & 35 & 15 & 15 & 35 & $\begin{array}{c}53,820 \\
(14,566)\end{array}$ & $\begin{array}{c}84,554 \\
(22,884)\end{array}$ & $\begin{array}{l}30,734 \\
(8318)\end{array}$ \\
\hline $3 \mathrm{C}$ & 28 & 10 & 27 & 35 & $\begin{array}{c}59,080 \\
(15,990)\end{array}$ & $\begin{array}{c}85,633 \\
(23,176)\end{array}$ & $\begin{array}{l}26,553 \\
(7187)\end{array}$ \\
\hline
\end{tabular}

Table 12. Comparison of manufacturing costs of pyrotechnic compositions from the M-2 group for model 2, batch of $2000 \mathrm{~kg}$ (4409 lb) of pyrotechnic compositions.

\begin{tabular}{|c|c|c|c|c|c|c|c|}
\hline \multirow{2}{*}{ Designation } & \multicolumn{4}{|c|}{ Chemical Composition (\%) } & \multirow{2}{*}{$\begin{array}{l}\text { Price } \\
\text { (1981) } \\
\text { PLN } \\
\text { (USD) }\end{array}$} & \multirow{2}{*}{$\begin{array}{l}\text { Price } \\
\text { (2021) } \\
\text { PLN } \\
\text { (USD) }\end{array}$} & \multirow{2}{*}{$\begin{array}{c}\text { Price Difference Compared } \\
\text { to 1981 PLN } \\
\text { (USD)vspace-16pt }\end{array}$} \\
\hline & \multicolumn{2}{|c|}{$\mathrm{Ba}\left(\mathrm{NO}_{3}\right)_{2}$} & PAM & $\mathrm{S}$ & & & \\
\hline M-0 & \multicolumn{2}{|c|}{64} & 18 & 18 & $\begin{array}{c}44,936 \\
(12,162) \\
\end{array}$ & $\begin{array}{l}111,518 \\
(30,182) \\
\end{array}$ & $\begin{array}{c}66,582 \\
(18,020) \\
\end{array}$ \\
\hline \multirow[t]{2}{*}{ Designation } & \multicolumn{4}{|c|}{ Chemical Composition (\%) } & $\begin{array}{l}\text { Price } \\
\text { (1981) }\end{array}$ & $\begin{array}{l}\text { Price } \\
(2021)\end{array}$ & $\begin{array}{c}\text { Price Difference Compared } \\
\text { to } 1981 \text { PLN }\end{array}$ \\
\hline & $\mathrm{KClO}_{4}$ & $\mathrm{Fe}_{2} \mathrm{O}_{3}$ & Al & $\mathrm{S}$ & (USD) & (USD) & (USD) \\
\hline $4 \mathrm{~A}$ & 36 & 18 & 26 & 20 & $\begin{array}{c}72,744 \\
(19,688)\end{array}$ & $\begin{array}{c}98,549 \\
(26,672)\end{array}$ & $\begin{array}{l}25,805 \\
(6984)\end{array}$ \\
\hline $4 \mathrm{~B}$ & 35 & 18 & 27 & 20 & $\begin{array}{c}73,104 \\
(19,785)\end{array}$ & $\begin{array}{c}98,249 \\
(25,590)\end{array}$ & $\begin{array}{l}25,145 \\
(6805)\end{array}$ \\
\hline $4 \mathrm{C}$ & 39 & 14 & 27 & 20 & $\begin{array}{c}76,352 \\
(20,664)\end{array}$ & $\begin{array}{l}101,993 \\
(27,604)\end{array}$ & $\begin{array}{l}25,641 \\
(6939)\end{array}$ \\
\hline $5 \mathrm{~A}$ & 35 & 20 & 20 & 25 & $\begin{array}{c}64,460 \\
(17,446)\end{array}$ & $\begin{array}{c}91,776 \\
(24,839)\end{array}$ & $\begin{array}{l}27,316 \\
(7393)\end{array}$ \\
\hline $5 \mathrm{~B}$ & 37 & 17 & 21 & 25 & $\begin{array}{c}67,256 \\
(18,202)\end{array}$ & $\begin{array}{c}94,284 \\
(25,517)\end{array}$ & $\begin{array}{l}27,028 \\
(7315)\end{array}$ \\
\hline $5 \mathrm{C}$ & 38 & 15 & 22 & 25 & $\begin{array}{c}69,240 \\
(18,739)\end{array}$ & $\begin{array}{c}95,856 \\
(25,943)\end{array}$ & $\begin{array}{l}26,616 \\
(7203)\end{array}$ \\
\hline $6 \mathrm{~A}$ & 30 & 20 & 20 & 30 & $\begin{array}{c}59,960 \\
(16,228)\end{array}$ & $\begin{array}{c}85,075 \\
(23,025)\end{array}$ & $\begin{array}{l}25,115 \\
(6797)\end{array}$ \\
\hline $6 \mathrm{~B}$ & 37 & 13 & 20 & 30 & $\begin{array}{c}65,644 \\
(17,766)\end{array}$ & $\begin{array}{c}91,627 \\
(24,798)\end{array}$ & $\begin{array}{l}25,983 \\
(7032)\end{array}$ \\
\hline $6 \mathrm{C}$ & 29 & 18 & 23 & 30 & $\begin{array}{c}62,664 \\
(16,960)\end{array}$ & $\begin{array}{c}86,047 \\
(23,288)\end{array}$ & $\begin{array}{l}23,383 \\
(6328)\end{array}$ \\
\hline
\end{tabular}

The manufacturing cost calculated for model 1-a production batch of $500 \mathrm{~kg}(1102 \mathrm{lb})$ of pyrotechnic composition from groups M-1 and M-2-is in the range of PLN 21,138-27,182 (USD 5721-7357) and is, on average, PLN 7112(USD 1925), higher than in 1981. 
The lowest manufacturing costs were reported for compositions:

- $\quad$ 3B-PLN 21,138 (USD 5721);

- $\quad$ 6A-PLN 21,269 (USD 5756);

- $\quad$ 3C-PLN 21,408 (USD 5794);

- $\quad$ 6A-PLN 21,512 (USD 5822);

- $\quad$ 2A-PLN 21,774 (USD 5893).

In contrast, the highest cost was calculated for compositions:

- $\quad$ 1B-PLN 27,182 (USD 7357);

- $\quad$ 1C-PLN 26,564 (USD 7189);

- $\quad$ 1A-PLN 25,928 (USD 7017);

- $\quad$ 4C-PLN 25,498 (USD 6901).

The difference between the lowest and the highest costs (the range of a set of data) shall be considered as potential production savings. For the adopted model, this value in 2021 is PLN 6044 (USD 1636).

For model 2, the cost of manufacturing a larger production batch-2000 kg (4409 Ib) of pyrotechnic compositions from groups M-1 and M-2-is correspondingly higher and is in the range of PLN 84,554-108,730 (USD 22,884-28,069). Compared to 1981, it is on average PLN 28,450 (USD 7700); it is more expensive to manufacture such a large production batch. The lowest manufacturing costs were reported for compositions:

- $\quad$ 3B-PLN 84,554 (USD 22,884);

- $\quad$ 6A-PLN 85,075 (USD 23,025);

- $\quad$ 3C-PLN 85,633 (USD 23,176);

- $\quad$ 6C-PLN 86,047 (USD 23,288);

- $\quad$ 2A-PLN 87,096 (USD 23,572).

In contrast, the highest cost was calculated for compositions:

- $\quad$ 1B-PLN 108,730 (USD 29,427);

- $\quad$ 1C-PLN 106,258 (USD 28,758);

- $\quad$ 1A-PLN 103,714 (USD 28,069);

- $\quad$ 4C-PLN 101,993 (USD 27,604).

The range of a set of data concerning total manufacturing costs in 2021 is PLN 24,176 (USD 6543), and this is the maximum amount of savings that can be achieved on the purchase of raw materials needed to manufacture $2000 \mathrm{~kg}$ (4409 lb) of individual prospective compositions.

It is worth noting that in the free market in the 21st century, when purchasing wholesale quantities of the raw materials needed to manufacture large amounts of the composition presented as the example models described in the paper, there is a possibility of negotiating prices; thus, the actual costs of obtaining $500 \mathrm{~kg}(1102 \mathrm{lb})$ and $2000 \mathrm{~kg}(4409 \mathrm{lb})$ of particular compositions, in reality, might even be lower than calculated.

\section{Summary}

- The analysis of changes in the prices of raw materials, and their impact on the costs of manufacturing prospective pyrotechnic compositions in 1981 and 2021, allows us to formulate the following conclusions:

- The significant increase in the price of barium nitrate(V), used in the production of the M-0 reference composition, translates into an approximately 1.5 -fold increase in the unit price of this pyrotechnic composition. This change causes, both individually and on a large scale, the manufacturing cost of the M- 0 composition to be higher than that of the others. This results in a decrease in the economic viability of using this component as an oxidiser.

- The large reduction in the cost of flake aluminium compared to 1981, and the equalisation with the price of this metal in powder form means that, at present, the use of this component in flake form can be economically justified if this is due to the technology. 
- Despite the passage of time, sulphur remains the cheapest component used in the manufacture of pyrotechnic composition. The use of this raw material in larger quantities when technologically possible, without significant deterioration of the functional properties of the final pyrotechnic composition, is highly desirable for financial reasons.

- The lowest manufacturing costs, both individually and for the adopted models, were calculated for the compositions: 3B, 6A, 3C, 6C and 2A.

- The highest manufacturing costs, both individually and for the adopted models, were calculated for the compositions: 1B, 1C, 1A and $4 \mathrm{C}$, respectively.

- Taking into account both the acoustic effect (being the subject of the study in parts I and II of the publication) and the cost criterion, the lowest manufacturing price while ensuring optimum performance was obtained for mixture 6A.

- Cost analysis is a tool allowing evaluation of the profitability of manufacturing individual pyrotechnic composites. By comparing the obtained values with the performance parameters of pyrotechnic composition, it is possible to select compositions that are optimal concerning technical and economic issues.

Author Contributions: Conceptualization, K.B.; Methodology, J.B.; Writing-original draft, K.B.; Writing—original draft preparation, K.B.; Writing—review \& editing, J.B. All authors have read and agreed to the published version of the manuscript.

Funding: This research received no external funding.

Institutional Review Board Statement: Not applicable.

Informed Consent Statement: Not applicable.

Data Availability Statement: The data presented in this study are available on request from the corresponding author (K.B.).

Conflicts of Interest: The authors declare no conflict of interest.

\section{References and Notes}

1. Szydłowski, A. Podstawy Pirotechniki. (Basics of Pyrotechnics); Wydawnictwo MON: Warsaw, Poland, 1957.

2. Conkling, J.A. Chemistry of Pyrotechnics—Basic Principles and Theory; CRC Press: New York, NY, USA, 1985.

3. Biegańska, J. Ocena szkodliwości ogni sztucznych dla widzów i środowiska (Evaluation of harmfulness of fireworks to humans and environment). Ekol. Tech. 2000, 8, 78-82.

4. Pawłowska, J. Opracowanie Nowych Składów Mieszanek Pirotechnicznych Pozorujących Odpowiedni Efekt Akustyczny (Development of New Compositions of Pyrotechnic Mixtures Simulating an Appropriate Acoustic Effect). Master's Thesis, Silesian University of Technology, Gliwice, Poland, 1981.

5. Barański, K. Analysis of the Possibility of Using "Green Pyrotechnics" in the Detonators MW. Ph.D. Thesis, AGH University of Science and Technology in Cracow, Cracow, Poland, 27 September 2019.

6. Berger, B. Parameters Influencing the Pyrotechnic Reaction. Propellants Explos. Pyrotech. 2005, 30. [CrossRef]

7. Conkling, J.; Mocella, C.J. Chemistry of Pyrotechnic Basic Principles and Theory; CRC Press: Boca Raton, FL, USA, 2010.

8. PN-V-04002-2:1996; Mieszaniny Pirotechniczne i Wyroby Pirotechniczne. Trwałość Fizyczna i Chemiczna. Oznaczanie Higroskopijności. (Pyrotechnic Mixtures and Pyrotechnic Articles. Physical and Chemical Durability. Determination of Hygroscopicity). Polish Committee for Standardization: Warsaw, Poland, 1996.

9. PN-V-04002-8:1996; Mieszaniny Pirotechniczne i Wyroby Pirotechniczne. Trwałość Fizyczna i Chemiczna. Badania Odporności na Długoletnie Składowanie za Pomocą Zmiennych Cykli Temperaturowych. (Pyrotechnic Mixtures and Pyrotechnic Articles. Physical and Chemical Durability. Research on Resistance to Long-Term Storage by Means of Variable Temperature Cycles). Polish Committee for Standardization: Warsaw, Poland, 1996.

10. PN-EN 13631-3:2006; Materiały Wybuchowe do Użytku Cywilnego-Materiały Wybuchowe Kruszące-Część 3: Oznaczanie Wrażliwości Materiałów Wybuchowych na Tarcie. (Explosives for Civil Uses-High Explosives-Part 3: Determination of Sensitiveness to Friction of Explosives). Polish Committee for Standardization: Warsaw, Poland, 2006.

11. BN-76/6091-08,1997; Materiały Wybuchowe Górnicze. Oznaczanie Temperatury Rozkładu. (Mining Explosives. Determination of the Decomposition Temperature). Polish Committee for Standardization: Warsaw, Poland, 1997.

12. PN-EN 13631-2:2004; Materiały Wybuchowe do Użytku Cywilnego-Materiały Kruszące-Część 2: Oznaczanie Stabilności Termicznej Materiałów Wybuchowych (Explosives for Civil Uses_-High Explosives_Part 2: Determination of Thermal Stability of Explosives). Polish Committee for Standardization: Warsaw, Poland, 2004. 
13. BN-76/6091-41,1976; Materiały Wybuchowe-Oznaczanie Stałości Metodą Różnicowej Analizy Termicznej. (ExplosivesDetermination of Constancy by Differential Thermal Analysis). Polish Committee for Standardization: Warsaw, Poland, 1976.

14. Directive 2007/23/EC of the European Parliament and of the Council of 23 May 2007 on the Placing on the Market of Pyrotechnic Articles.

15. Directive 2013/29/EU of the European Parliament and of the Council of 12 June 2013 on the Harmonisation of the Laws of the Member States Relating to the Making Available on the Market of Pyrotechnic Articles.

16. Biegańska, J.; Barański, K. Experiments with Pyrotechnic Compositions Based on a Mathematical Model-Part I Evaluation of the Applicability of Mathematical Models in Developing Pyrotechnic Compositions Producing an Acoustic Effect. Energies 2021, 14, 8548. [CrossRef]

17. Biegańska, J.; Barański, K. Experiments with Pyrotechnic Compositions Based on a Mathematical Model—Part II Pyrotechnic Compositions Producing an Acoustic Effect with Optimum Properties Producing an Acoustic Effect. Energies 2022, 15, 794. [CrossRef]

18. Katalog cen (Price catalog) Archival data from 1981 of the Union of Plastics and Paints "Plastofarb". Gliwice, Poland, 1981.

19. "Fabrykaognia.pl"-Information on the Price of Barium Nitrate (V) Ba(NO3)2. Available online: http:/ / www.fabrykaognia.pl/ sklep2/55-azotan-potasu-kno3.html (accessed on 11 January 2021).

20. Shop "Fabrykaognia.pl"-Information on the Price of Powdered Aluminum. Available online: http:// fabrykaognia.pl/sklep2/3 22-aluminium-atomizowane.html (accessed on 11 January 2021).

21. Allegro.pl Auction Portal-information on the price of iron oxide (III). Available online: https://allegro.pl/oferta/tlenek-zelazaiii-czerwony-czysty-500g-8755124822 (accessed on 11 January 2021).

22. Shop "Fabrykaognia.pl"-Information on the Price of Ground sulfur. Available online: http://www.fabrykaognia.pl/sklep2/60siarka-mielona.html (accessed on 11 January 2021).

23. Internal Documents of the AGH-UST University Regarding the Supply and Sale of Chemical Reagents. Available online: https:/ / dok.agh.edu.pl/doc.php?typ=69\&nr=77\&sort=datar (accessed on 11 January 2021).

24. Shop "Pyro Garage"-Information on the Price of Aluminum Flake. Available online: https://www.pyrogarage.pl/produkt/ odczynniki/proszki-metali/aluminium-bright-al/ (accessed on 11 December 2020).

25. eBay Auction Portal Website-Barium Nitrate (V) Price Information. Available online: https://www.ebay.com/itm/4033999517 48?epid=686726698\&hash=item5dec82c584:g:QKoAAOSwyg1h2eXU (accessed on 11 January 2021).

26. eBay Auction Portal Website-Iron(III) Oxide Price Information. Available online: https://www.ebay.com/itm/124911330143 (accessed on 11 January 2021).

27. Fischer Scientific Website Shop-Potassium Chlorate (VII) Price Information. Available online: https://www.fishersci.at/shop/ products/potassium-perchlorate-99-7/11463674/en (accessed on 11 January 2021).

28. eBay Auction Portal Website-Aluminium Powder Price Information. Available online: https://www.ebay.com/itm/2838199761 54?var=585247800191\&hash=item4214fd25da:g:HHYAAOSwleBftTYI (accessed on 11 January 2021).

29. Fireworks Cookbook Pyrotechnics Shop Website. Available online: https://www.fireworkscookbook.com/product/magnaliummg-al/ (accessed on 11 January 2021).

30. eBay Auction Portal Website-Sulphur Powder Price Information. Available online: https://www.ebay.com/itm/402580069108 ?hash=item5dbba45af4:g:N3oAAOSwTwRfwDAj (accessed on 11 January 2021).

31. Amazon Auction Portal Website-Iron(III) Oxide Price Information. Available online: https://www.amazon.co.uk/Iron-OxideEarthenware-StonewarePorcelain/dp/B09Q7LVJPT /ref=sr_1_4?crid=19QL6EG7JQK1G\&keywords=Iron(III)\%2Boxide\&qid= 1642596774\&sprefix=iron\%2Biii\%2Boxide \%2B\%2Caps\%2C87\&sr=8-4\&th=1 (accessed on 11 January 2021).

32. National Bank of Poland (NBP). Table 030/A/NBP/2021-Average USD Exchange Rate, as of February 15, 2021. Available online: http:/ / rss.nbp.pl/kursy/TabRss.aspx?n=2021/a/21a030 (accessed on 15 February 2021). 